\title{
Molecular approaches for eco-epidemiological studies of Paracoccidioides brasiliensis
}

\author{
Virgínia Bodelão Richini-Pereira, Sandra de Moraes Gimenes Bosco, Raquel Cordeiro Theodoro, \\ Severino Assis da Graça Macoris, Eduardo Bagagli/+
}

Departamento de Microbiologia e Imunologia, Instituto de Biociências, Universidade Estadual Paulista, Distrito de Rubião Júnior s/n, 18618-000 Botucatu, SP, Brasil

\begin{abstract}
Medical mycology has greatly benefited from the introduction of molecular techniques. New knowledge on molecular genetics has provided both theoretical and practical frameworks, permitting important advances in our understanding of several aspects of pathogenic fungi. Considering Paracoccidioides brasiliensis in particular, important eco-epidemiological aspects, such as environmental distribution and new hosts were clarified through molecular approaches. These methodologies also contributed to a better understanding about the genetic variability of this pathogen; thus, P. brasiliensis is now assumed to represent a species complex. The present review focuses on some recent findings about the current taxonomic status of $\mathrm{P}$. brasiliensis, its phylogenetic and speciation processes, as well as on some practical applications for the molecular detection of this pathogen in environmental and clinical materials.
\end{abstract}

Key words: Paracoccidioides brasiliensis - eco-epidemiology - PCR

Paracoccidioidomycosis (PCM) is the most important and prevalent systemic mycosis in Latin America, occurring mainly in Brazil, Colombia and Venezuela (Wanke \& Londero 1994). It is caused by Paracoccidioides brasiliensis, a thermally dimorphic fungus that grows as a yeast-like structure in host tissues or when cultured at $35-37^{\circ} \mathrm{C}$ and as a mycelium under saprobic conditions or when cultured at $\mathrm{rt}, 18-23^{\circ} \mathrm{C}$ (Lacaz 1994).

PCM-infection is believed to be acquired through the inhalation of conidia present in the environment, which is similar to other systemic mycoses also caused by dimorphic fungi and in which the lung is the main compromised organ (Gonzales-Ochoa 1956, Bustamante et al. 1985).

Although PCM is considered an endemic disease in many regions, there are few reports in the literature about the isolation of this pathogen from the environment, which has made ecological studies on $P$. brasiliensis difficult for mycologists (Shome \& Batista 1963, Negroni 1966, Albornoz 1971, Restrepo 1985, Silva-Vergara et al. 1998, Franco et al. 2000). There have been references to $P$. brasiliensis isolation from bat and penguin faeces and dog food. However, these were casual remarks with no reproducibility (Grose \& Tamsitt 1965, Gezuele 1989, Ferreira et al. 1990). Besides, the lack of outbreaks and the prolonged latency period of this disease, together with human migration, allow the exact infection source to remain unknown (Restrepo 1985).

\footnotetext{
Financial support: Fapesp (05/56771-9 and 06/03597-4)

+ Corresponding author: bagagli@ibb.unesp.br

Received 15 November 2008

Accepted 15 April 2009
}

An important clue for ecological studies on P. brasiliensis was the finding of naturally infected nine-banded armadillo (Dasypus novemcinctus) in endemic areas (Naiff et al. 1986, Bagagli et al. 1998, 2003, Corredor et al. 1999, Silva-Vergara \& Martínez 1999). The fungus was also isolated from another armadillo species, Cabassous centralis, reinforcing that armadillos are in constant contact with the pathogen in the environment (Corredor et al. 2005). The systematic recovery of $P$. brasiliensis from armadillo tissues has demonstrated the importance of this animal in PCM endemic areas, helping locate hot spots of fungal occurrence in some environments and suggested valuable insights about its evolutionary aspects (Bagagli et al. 2006, 2008).

The environment represented by the armadillo burrow and its surroundings, associated with biotic and abiotic features, may contribute to the development of the fungus saprobic stage in nature, as already demonstrated by Terçarioli et al. (2007).

For a long time, armadillos had been the only wild animal species in which fungus recovery from tissue cultures was possible, although many attempts have been made in other animal species from PCM endemic areas. Recently, other wild mammals such as guinea pig (Cavia aperea), porcupine (Sphiggurus spinosus), raccoon (Procyon cancrivorus) and grison (Gallictis vittata) have been recognized through molecular methods as new hosts for this infection (Richini-Pereira et al. 2008).

Learning about the natural reservoirs of this pathogenic fungus may contribute to mapping of endemic areas and to a better understanding of its eco-epidemiological features. However, some questions still need to be answered, such as: does the fungus need some special substrate or a specific period to grow? Which are the most appropriate environmental conditions, climates and soil types? Which host-parasite relationship does the 
fungus establish? Is there another infection route, besides the airborne route?

Medical mycology has extensively benefited from the great development of molecular biology in the latest years. Thus, the aim of this review is to present some recent advances in the understanding of the eco-epidemiology of $P$. brasiliensis and related species through molecular approaches.

\section{Molecular biology has demonstrated that $P$. brasi- liensis belongs to a peculiar Ascomycota family}

Morphological and molecular findings have suggested that the main pathogenic fungi causing systemic mycosis had been classified into Ajellomycethaceae, a new family of vertebrate-associated Onygenales, which includes fungi of the genera Histoplasma, Blastomyces, Emmonsia and Paracoccidioides (Untereiner et al. 2004). The correct taxonomic position of these fungi has opened new possibilities for their study and understanding of their eco-epidemiological relationships with their respective hosts.

This fungal group (Onygenales, Onygenaceae sensu lato) presents several common mycological and ecological features such as dimorphism, arthroconidia production and restricted geographic distribution. In addition, the natural affinity of some of its members, such as Blastomyces dermatitidis and Histoplasma capsulatum, for animal product derivatives or remnants like faeces and uric acid is well documented (Baumgardner \& Paretsky 1999, Restrepo 2000, Untereiner et al. 2004).

Several lines of evidence indicate that $P$. brasiliensis is phylogenetically closer to Lacazia loboi than to Blastomyces dermatididis, Emmonsia parva and H. capsulatum (Bialek et al. 2000, Herr et al. 2001). It must be emphasized that $L$. loboi could not yet be cultured on standard media and is therefore considered an obligate parasite (Taborda et al. 1999, Herr et al. 2001). This suggests a possible tendency for reduction or extinction of the fungus saprobic form in nature. Lacaziosis, the mycosis caused by $L$. loboi, is acquired through traumatic route and evolves typically as a chronic subcutaneous infection. It occurs in a restricted region of the Brazilian Amazon, Surinam and some other countries in northern South America and Central America. It has also been observed in some wild aquatic mammals, especially Atlantic dolphins (Herr et al. 2001).

It must be considered that this phylogenetic group (Onygenales) includes the species E. parva and Emmonsia crescens that cause adiaspiromycosis, a localized lung infection of cosmopolitan distribution, both in wild animals and humans (Hubalék et al. 1998). Some aspects of their saprobic and parasitic stages have led Emmonsia species to be considered close relatives of dimorphic fungi (Emmons \& Ashburn 1942, Sigler 1996, Peterson \& Sigler 1998). Their occurrence has been related to the agroecosystem and their highest abundance was observed in plant remnants and rodent burrows (Hubalék et al. 1998). The presence of this fungus has been reported in domestic and wild rodents (Zlatanov \& Genov 1975,
Hubalék et al. 1998), carnivores (Krivanec et al. 1980) and armadillos (Santos 1999).

Studies have also indicated that the different Onygenaceae (sensu lato) species may have originated in the Americas around 3-20 million years ago (Fisher et al. 2000) and some of the most important ones, such as Histoplasma and Paracoccidioides species, had certainly evolved in South America prior to the Panamanian Isthmus connection (Kasuga et al. 1999, 2003).

\section{Molecular phylogenetics indicates that $P$. brasilien- sis is a species complex}

Like all living organisms, $P$. brasiliensis has been shown to present a significant diversity, which has been well documented by different mycological, antigenic and virulence studies, as well as by molecular techniques (Franco et al. 1996, Calcagno et al. 1998, Sano et al. 1999, Hebeler-Barbosa et al. 2003a, b, Macoris et al. 2006, Puccia et al. 2008). Instead of a unique species, $P$. brasiliensis appears to contain several different cryptic species, as observed by phylogenetic studies using MultiLocus Sequence Type (MLST) (Matute et al. 2006a, Carrero et al. 2008), microsatellite analysis (Matute et al. 2006b) and prp 8 intein sequencing (Theodoro et al. 2008a). Unlike the morphological and biological concepts of species, which are rarely applicable to separate fungal species, the Phylogenetic Species Concept consider a species as a cluster of individuals that presents exclusive apomorphic characters and is genetically isolated from other species (i.e. individuals from different species are not exchanging alleles). According to this concept, the Phylogenetic Species Recognition (PSR) by MLST uses several nuclear genes and detects the species limits through genealogical concordance (the clade must be present in the majority of the single-locus genealogies) with high bootstrap and posterior probability values supporting the clades (Taylor et al. 2000).

Applying the PSR approach, Matute et al. (2006a, b) analysed eight regions of five nuclear coding genes: chitin synthase, $\beta$-glucan synthase, $\alpha$-tubulin, adenyl ribosylation factor and PbGP43 and also performed microsatellite analysis that revealed three distinct, previously unrecognised species: S1 (species 1 from Brazil, Argentina, Paraguay, Peru and Venezuela), PS2 (phylogenetic species 2 from Brazil and Venezuela) and PS3 (phylogenetic species from Colombia). They also observed that S1 and PS2 were both recombining sexual species, whereas PS3 was shown to be clonal. It is interesting to note that $\mathrm{S} 1$ and PS2 are sympatric but reproductively isolated, suggesting an intrinsic biological barrier to reproduction. The divergence time between PS2-PS3 was estimated as 8.048.37 mya through chitin synthase gene analysis (Matute et al. 2007). Those authors suggested that the speciation of PS3, geographically restricted to Colombia, could be attributed to dispersal, leading to genetic isolation of PS3 from S1 (allopatric speciation). The other speciation event that originated PS2 is still poorly understood. S1 and PS2 may be the result of sympatric speciation, the initial step of which is the existence of polymorphism, much more abundant in recombining species such as PS2 and S1. Therefore, two forms of a single species can be 
adapted to different conditions in their niche, leading to negatively selected interbreeding due to the low adaptive value of the hybrids (Coyne \& Orr 2004).

Recently, more P. brasiliensis isolates from the Central Region of Brazil were included in a new MLST analysis and showed a significant genetic divergence when compared with other S1, PS2 and PS3 isolates (Carrero et al. 2008, Teixeira 2008). This cluster of isolates was named $\mathrm{Pb} 01$-like, since the first studies that revealed such divergence were carried out with $\mathrm{Pb} 01$ isolate. Phylogenetic analyses with several nuclear encoding regions such as GP43, CH4, Actin, ODC, URA3, CHS2, FKS1, HSP70, Hydrophobin, Kex, Catalase A, Catalase $P$, Formamidase and Glyoxalase showed a significative genetic distance between $\mathrm{Pb} 01$ and the remaining genetic groups (Carrero et al. 2008). Pb01-like isolates form a well-supported clade for several nuclear coding genes, suggesting the existence of one more cryptic species of P. brasiliensis (Carrero et al. 2008, Teixeira 2008). The divergence time between Pb01-like and the remaining clades was estimated as 20 mya, a long evolutionary time (Teixeira 2008). However, it is not clear yet which factors (geographic, biotic and abiotic) could have contributed to the genetic isolation of this group right in the Central Region of Brazil. This Pb01 isolate, which has been the subject of genome and transcriptome projects (Felipe et al. 2005), also substantially differs from the others in the $h s p 70$ gene, which encodes a conserved heat shock protein. Four large insertions: one of four nucleotides, one of 16, a third one of 23 and another one of 21 (the last corresponds to a CT microsatellite), were observed in the $h s p 70$ gene of $\mathrm{Pb} 01$, relative to $P$. brasiliensis isolates from the other species (Teixeira et al. 2005, Theodoro et al. 2008b).

An additional molecular marker, the PRP8 intein, was used to recognize $P$. brasiliensis isolates of the different genetic groups (Theodoro et al 2008a). Inteins are coding sequences that are transcribed and translated with flanking sequences (exeins). After translation, inteins are excised by an autocatalytic process; then, the host protein assumes its normal conformation and can develop its function (Cooper \& Stevens 1995). These parasitic genes have been found in several vital proteins in all three domains of life and are widespread in fungi. The PRP8 intein is known to occur in important fungal pathogens such as Cryptococcus neoformans (varieties grubii and neoformans), Cryptococcus gattii, H. capsulatum and P. brasiliensis (Butler \& Poulter 2005, Butler et al. 2006). There are two intein types, mini-inteins and full-length inteins, both of which have a splicing domain. Full-length inteins additionally present an endonuclease domain that can play a homing function (Homing Endonuclease Gene or HEG), which makes intein a mobile genetic element, resulting in both the occupation of empty alleles and the duplication of parasitic genetic element (Liu 2000). These large inteins are expected to have more sequence variation in the endonuclease domain than in the splicing domain due to a more relaxed selection, especially if the HEG is no longer active (Gorgaten \& Hilario 2006), which makes inteins a promising source of phylogenetic information. In this assay, the
PRP8 inteins of 22 P. brasiliensis isolates belonging to all four previously recognized species were sequenced. The phylogenetic analysis clearly separated the isolates from the four species and revealed a significant difference between Pb01-like and the remaining species (Theodoro et al. 2008a). All evaluated P. brasiliensis isolates presented a full-length intein in their prp 8 gene. The HEG domain of PRP8 intein from P. brasiliensis appears to be inactive due to a substitution in the second aspartic acid residue, which is indispensable to its functionality. Although the degree of polymorphism in the PRP8 intein from $P$. brasiliensis was not as high as that in the commonly used nuclear-coding sequences, its sequence contains sufficient phylogenetic information to separate cryptic species of $P$. brasiliensis, constituting therefore a reliable additional molecular marker for this pathogen.

Since distinct cryptic species have been recognized through molecular techniques, it becomes easier to detect other biological features that could be associated with the different genetic groups. Theodoro et al. (2008b) detected some microscopic features of S1 and PS2 isolates that could be important candidates for a morphological differentiation between these two species. The isolates T10 and Bt84, representing PS2, seemed to have elongated yeast cells and presented a slower Mycelia-to-yeast transition when compared with the other isolates. In addition, Terçarioli et al. (2007) studied fungal growth and conidia production on Soil Extract Agar and observed that most S1 group isolates produced large quantities of conidia; this was not observed in PS2 group isolates. Both S1 and PS2 genetic groups are sympatric in the same endemic area; however, $\mathrm{S} 1$ is curiously much more frequent in both patients and armadillos, probably due to its higher conidium production (Bagagli et al. 2008). As a large number of isolates from different areas are molecularly characterized, the geographical distribution of such strains becomes clearer. Thus, S1 appears to be widely distributed, sympatrically occurring with PS2 in several endemic areas; the PS3 group is centralized in Colombia; and the Pb01-like group, in the Central Region of Brazil. The geographic distribution of the different genetic groups of the $P$. brasiliensis species complex is summarized in Figure, according to the currently available data.

Since prophylactic or treatment measures for PCM must include all genotypes and/or phenotypes of $P$. brasiliensis, the discovery of cryptic species increased the importance of comparative studies aiming to detect relevant phenotypic differences among species. These studies may be of help in correct diagnosis and treatment of PCM.

\section{Pathogen detection - clinical and environmental sources}

PCM diagnosis is usually made by microscopic detection of characteristic multibudding yeast cells and/or by isolation of fungal cultures from clinical specimens, histopathology of biopsied tissue and serological tests, especially including gp 43, a reference $P$. brasiliensis antigen (Lacaz 1994). Each of these procedures has advantages and disadvantages. Although a definitive diagnosis can be made through fungal culture, it must be considered 


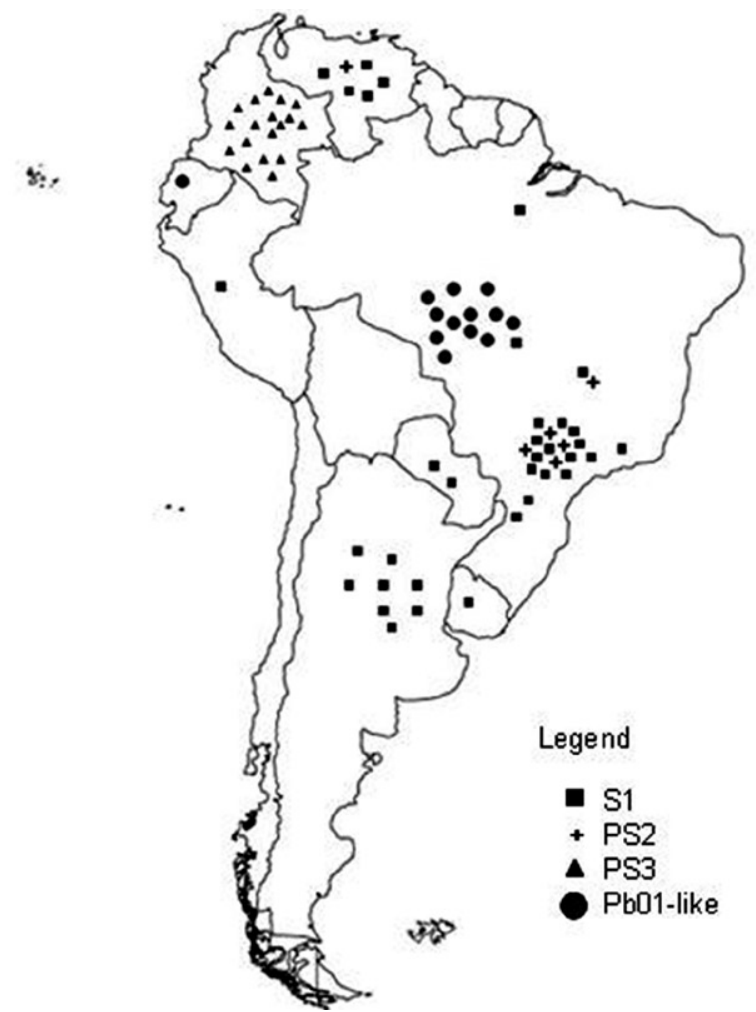

Geographic distribution of the different genetic groups of Paracoccidioides brasiliensis species complex, according to the actual available data. PS2: phylogenetic species 2 from Brazil and Venezuela; PS3: phylogenetic species from Colombia; S1: species 1 from Brazil, Argentina, Paraguay, Peru and Venezuela.

that such procedure involves high contamination risk, long incubation period and low sensitivity due to the low amounts of fungus in some clinical samples (Salina et al. 1998, Sano et al. 2001). In histological sections, the etiological agent might be undetected in some pauci-cellular samples or confused with other dimorphic fungi (Bialek et al. 2000). Several serology techniques using different $P$. brasiliensis antigen types have been employed for both diagnosis and monitoring therapy of patients; however, problems such as anergy and cross-reactivity as well as the specificity and sensitivity of the technique must be considered (Albuquerque et al. 2005).

Recent advances in molecular biology, mainly based on the PCR, provide powerful tools for the detection, identification and typing of different pathogen groups. The main genomic regions employed for primer designs for use in both clinical and environmental samples of $P$. brasiliensis are listed in Table.

Goldani et al. (1995) designed specific primers based on the $\beta$-actin gene which amplified a $62 \mathrm{bp}$-fragment not detected in other fungi such as $H$. capsulatum, B. dermatitidis, C. neoformans, Candida albicans, Aspergillus fumigatus, Saccharomyces cerevisiae and Pneumocystis carinii. Later, Goldani and Sugar (1998) employed this same set of primers to detect DNA of $P$. brasiliensis in blood from five experimentally infected mice and compared this result with culture. They concluded that the molecular approach was more sensitive rather than culture (100\% vs. $40 \%$, respectively) and suggest further evaluation of such approach in different clinical forms of PCM to assess the true value of this diagnostic method. PCR assays targeting the gp 43 gene (PbGP43) are widely used for the molecular detection of $P$. brasiliensis DNA in several types of samples Cisalpino et al. (1996) cloned and characterized the entire coding region of the gp43 gene, which comprises two exons interrupted by a 78bpintron. After this study, several sets of primers were designed and employed for molecular diagnosis. Gomes et al. (2000) combined five primer pairs and suggested a PCR using the PC2-PC6 primer pair for direct amplification from clinical material (sputum) or for nested-PCR following amplification with the PC1-PC5 primer set. In an experimental model infected with yeast cells of $H$. capsulatum and P. brasiliensis, Bialek et al. (2000) employed a nested-PCR, also based on $g p 43$, with high sensitivity and specificity for the sets of primers para I/II and para III/IV. Using these same sets of primers, Ricci et al. (2007) demonstrated $30 \%$ positivity in pathogen detection in biopsies from PCM-patients. Those authors emphasized that this low positivity might be due to the procedures used for fixation, paraffin embedding and storage of the material, which favoured DNA degradation and to the use of primers for regions of gp43 that have proven to be polymorphic. This fact may have interfered with the annealing of the primers employed (Morais et al. 2000, San-Blas et al. 2002). Since gp43 is a highly polymorphic gene that clearly separates the four cryptic species of $P$. brasiliensis (Matute et al. 2006a, Carrero et al. 2008, Teixeira 2008), PCR based on this genomic region is now indicated not only for pathogen detection, but also for genotyping of clinical samples. By using this strategy, Ricci et al. (2008) evaluated and distinguished between S1-PS2 from paraffin-embedded tissue.

Besides the gp43 glycoprotein, a 27-kDa antigen protein was cloned, sequenced and characterized by McEwen et al. (1996). The use of the LO and UP primer combination allowed the detection of $P$. brasiliensis DNA in tissue samples of armadillos and inoculated mice as well as in artificially contaminated soil (Corredor et al. 1999, Díez et al. 1999).

Internal transcribed spacer (ITS) regions, including the 5.8S ribosomal RNA of P. brasiliensis, are also employed for molecular detection and distinction from other fungal species. It is known that ribosomal DNA (rDNA) genes are present in all microorganisms and have regions that accumulate mutations both at slow (28S, 5.8S and 18S) and high (ITS1 and ITS2) rates over time. The first regions provide a molecular basis for establishing phylogenetic relationships among taxonomic levels above genus and the second regions are useful for the separation between genera and species. Besides, this target provides higher sensitivity to PCR due to its multiple copies per genome (more than 100 copies) (White et al. 1990, Iwen et al. 2002). This region has been considered the main candidate for a Barcoding system of fungal identification (Buckley 2008).

PCR of rDNA (5.8S-ITS) can be amplified by panfungal primers and the sensitivity and specificity of this reaction may be significantly improved by Nested-PCR with species-specific inner primers. Using this method, 


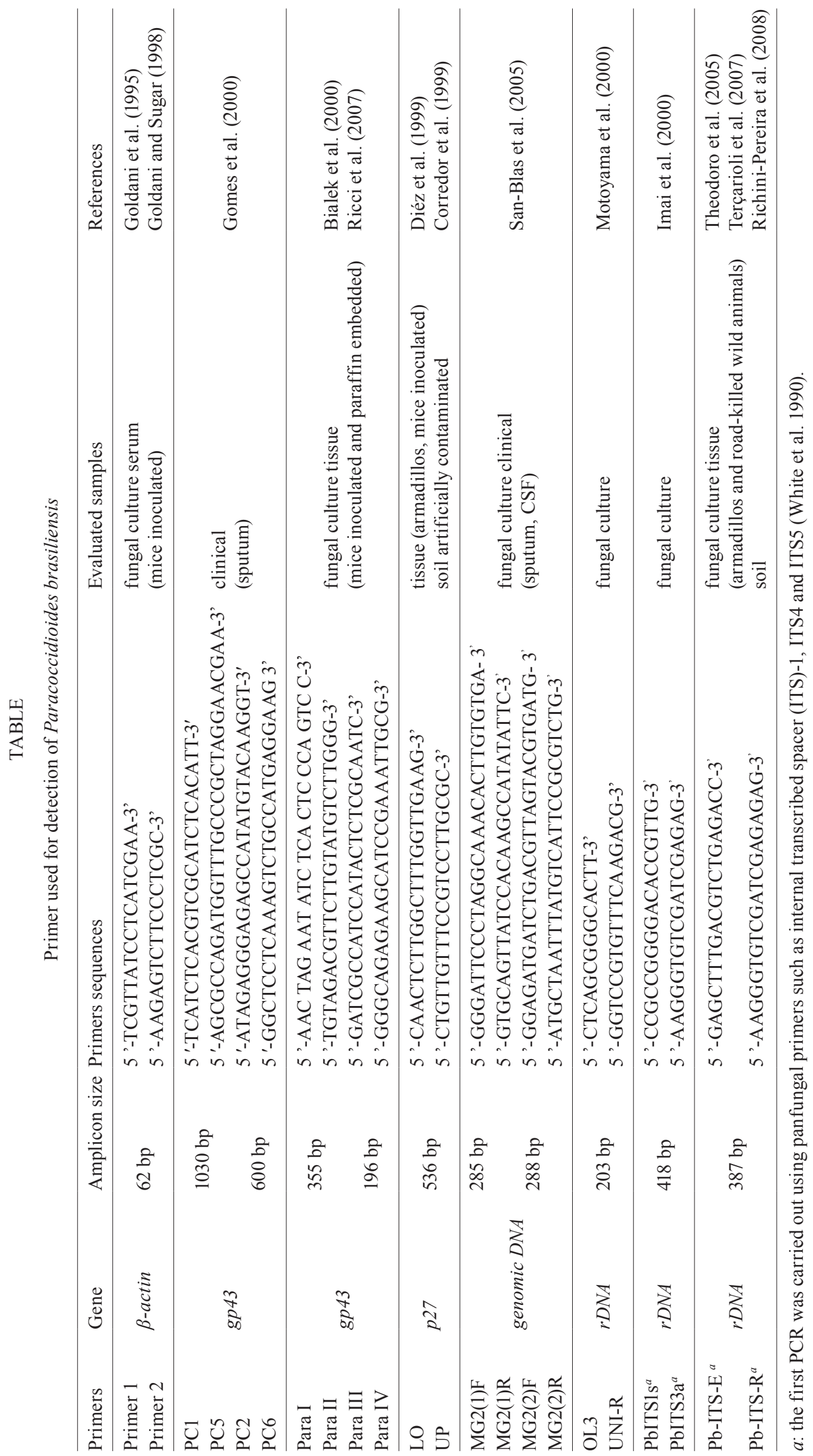


Imai et al. (2000) designed a set of primers, PbITS1s and PbITS3a, for nested-PCR and identified 29 P. brasiliensis strains by means of a specific 418bp-fragment, which was not detected in A. fumigatus, B. dermatididis, $C$. albicans, $C$. neoformans, $H$. capsulatum, or Penicillium marneffei. Motoyama et al. (2000) employed the OL3 and UNI-R primer combination for PCR and obtained a 203bp-fragment when P. brasiliensis (Pb01) DNA was used as the template. These primers were capable of discriminating between $P$. brasiliensis and $H$. capsulatum. A nested-PCR, also using species-specific inner primers (PbITSE and PbITSR) derived from ITS-5.8S rDNA, was developed for detection of $P$. brasiliensis in soil (Theodoro et al. 2005, Terçarioli et al. 2007). This technique also proved to be useful for fungal detection in road-killed wild animals (Richini-Pereira et al. 2008).

As $P$. brasiliensis actually consists of a species complex with distinct genetic groups, it must be emphasized that all molecular protocols should be re-evaluated both in silico and experimentally to detect any genotype that cause PCM in endemic areas.

\section{REFERENCES}

Albornoz MB 1971. Isolation of Paracoccidioides brasiliensis from rural soil in Venezuela. Sabouraudia 9: 248-253.

Albuquerque CF, Silva SHM, Camargo ZP 2005. Improvement of the specificity of na enzyme-linked immunosorbent assay for diagnosis of paracoccidioidomycosis. J Clin Microbiol 43: 1944-1946.

Bagagli E, Bosco SMG, Theodoro RC, Franco M 2006. Phylogenetic and evolutionary aspects of Paracoccidioides brasiliensis reveal a long coexistence with animal hosts that explain several biological features of the pathogen. Infect Genet Evol 6: 344-351.

Bagagli E, Franco M, Bosco SMG, Hebeler-Barbosa F, Trinca LA, Montenegro MR 2003. High frequency of Paracoccidioides brasiliensis infection in armadillo (Dasypus novemcinctus): an ecological study. Med Mycol 41: 217-223.

Bagagli E, Sano A, Coelho KIR, Alquati S, Miyaji M, Camargo ZP, Gomes G, Franco M, Montenegro MR 1998. Isolation of Paracoccidioides brasiliensis from armadillos (Dasypus novemcinctus) captured in an endemic area of paracoccidioidomycosis. $\mathrm{Am}$ J Trop Med Hyg 58: 505-512.

Bagagli E, Theodoro RC, Bosco SMG, McEwen J 2008. Paracoccidioides brasiliensis: phylogenetic and ecological aspects. Mycopathologia 165: 197-207.

Baumgardner DJ, Paretsky DP 1999. The in vitro isolation of Blastomyces dermatitidis from a woodpile in North Central Wisconsin, USA. Med Mycol 37: 163-168.

Bialek R, Ibricevic A, Aepinus C, Najvar Lk, Fothergill AW, Knobloch J, Graybill JR 2000. Detection of Paracoccidioides brasiliensis in tissue samples by a nested PCR assay. J Clin Microbiol 38: 2940-2942.

Buckley M 2008. The fungal kingdom diverse and essential roles in earth's ecosystem. American Academy of Microbiology, Washington, $44 \mathrm{pp}$.

Bustamante B, McEwen JG, Tabares AM, Arango M, Restrepo A 1985. Characteristics of the conidia produced by the mycelial form of Paracoccidioides brasiliensis. Sabouraudia 23: 407-414.

Butler ML, Gray J, Goodwin TJD, Poulter RTM 2006. The distribution and evolutionary history of the PRP8 intein. BMC Evol Biol 6: $1-26$.
Butler ML, Poulter RTM 2005. The PRP8 inteins in Cryptococcus are a source of phylogenetic and epidemiological information. Fungal Genet Biol 42: 452-463.

Calgagno AM, Nino-Veja G, San-Blas F, San-Blas G 1998. Geographic discrimination of Paracoccidioides brasiliensis strains by randomly amplified polymorphic DNA analysis. J Clin Microbiol 36: 1733-1736.

Carrero LL, Niño-Vega G, Teixeira MM, Carvalho MJA, Soares CMA, Pereira M, Jesuíno RSA, McEween JG, Mendoza L, Taylor JW, Felipe MS, San-Blas G 2008. New Paracoccidioides brasiliensis isolate reveals unexpected genomic variability in this human pathogen. Fung Genet Biol 45: 605-612.

Cisalpino PS, Puccia R, Yamauchi LM, Cano MI, Silveira JF, Travassos LR 1996. Cloning, characterization and epitope expression of the major diagnostic antigen of Paracoccidioides brasiliensis. J Biol Chem 271: 4553-4560.

Cooper AA, Stevens TH 1995. Protein splicing: self-splicing of genetically mobile elements at the protein level. Trends Biochem Sci 20: 351-356.

Corredor GG, Castaño JH, Peralta LA, Díez S, Arango M, McEwen J, Restrepo A 1999. Isolation of Paracoccidioides brasiliensis from the nine-banded armadillo Dasypus novemcinctus in an endemic area for paracoccidioidomycosis in Colombia. Rev Iberoam Micol 16: 216-220.

Corredor GG, Peralta LA, Castaño JH, Zuluaga JS, Henao B, Arango M, Tabares AM, Matute DR, McEwen JG, Restrepo A 2005. The naked-tailed armadillo Cabassous centralis (Miller 1899): a new host to Paracoccidiodes brasiliensis. Molecular identification of the isolate. Med Mycol 43: 275-280.

Coyne JA, Orr HA 2004. Speciation. Sinauer Associates, Sunderland, $545 \mathrm{pp}$.

Díez S, Garcia EA, Pino PA, Botero S, Corredor GG, Peralta LA, Castaño JH, Restrepo A, McEwen JG 1999. PCR with Paracoccidioides brasiliensis specific primers: potential use in ecological studies. Rev Inst Med Trop Sao Paulo 41: 351-358.

Emmons CW, Ashburn LL 1942. The isolation of Haplosporangium parvum n. sp. and Coccidioides immitis from wild rodents. Public Health Rep 57: 1715-1727.

Felipe MS, Torres FA, Maranhão AQ, Silva-Pereira I, Poças-Fonseca MJ, Campos EG, Moraes LM, Arraes FB, Carvalho MJ, Andrade RV, Nicola AM, Teixeira MM, Jesuíno RS, Pereira M, Soares CM, Brígido MM 2005. Functional genome of the human pathogenic fungus Paracoccidioides brasiliensis. Fems Immunol Med Microbiol 45: 369-381.

Ferreira MS, Freitas LS, Lacaz CS, Del Negro GM, Aielo NT, Garcia NM, Assis CM, Salebian A, Heris-Vaccari EM 1990. Isolation and characterization of a Paracoccidioides brasiliensis strain in dogfood probably contaminated with soil in Uberlândia, Brazil. J Med Vet Mycol 28: 253-256.

Fisher MC, Koenig GL, White TJ, Taylor JW 2000. A test for concordance between the multilocus genealogies of genes and microsatellites in the pathogenic fungus Coccidioides immitis. Mol Biol Evol 17: 1164-1174.

Franco M, Bagagli E, Cunha M, Chamma LG, Fecchio D 1996. Paracoccidioides brasiliensis antigen batches from the same isolate show immunological and biochemical differences. Mycopathologia 135: 13-19.

Franco M, Bagagli E, Scapolio S, Lacaz CS 2000. A critical analysis of isolation of Paracoccidioides brasiliensis from soil. Med Mycol 38: 185-191.

Gezuele E 1989. Aislamento de Paracoccidioides sp. de heces de 
pinguino de la Antártida. In International Meeting on Paracoccidioidomycosis 4, Anais, Abstract B2, Caracas, p. B-2.

Goldani LZ, Maia AL, Sugar AM 1995. Cloning and nucleotide sequence of a specific DNA fragment from Paracoccidioides brasiliensis. J Clin Microbiol 33: 1652-1654.

Goldani LZ, Sugar AM 1998. Short report: use of the polymerase chain reaction to detect Paracoccidioides brasiliensis in murine paracoccidioidomycosis. Am J Trop Med Hyg 58: 152-153.

Gomes GM, Cisalpino PS, Taborda CP, Camargo ZP 2000. PCR for diagnosis of paracoccidioidomycosis. J Clin Microbiol 38: 3478-3480.

Gonzales-Ochoa A 1956. Classificación clínica de las micoses. Rev Int Salubr Enferm Trop (Mex) 16: 1.

Gorgaten JP, Hilario E 2006. Inteins, introns and homing endonucleases: recent revelations about the life cycle of parasitic genetic elements. BMC Evol Biol 6: 1-5.

Grose E, Tamsitt JR 1965. Paracoccidioides brasiliensis recovered from the intestinal tract of three bats (Artibeus lituratus) in Colombia, South America. Sabouraudia 4: 124-125.

Hebeler-Barbosa F, Montenegro MR, Bagagli E 2003a. Virulence profiles of ten Paracoccidioides brasiliensis isolates obtained from armadillos (Dasypus novemcinctus). Med Mycol 41: 89-96.

Hebeler-Barbosa F, Morais FV, Montenegro MR, Kuramae EE, Montes B, McEwen JG, Puccia R, Bagagli E 2003b. Sequence comparison of the internal transcribed spacer regions and gp 43 in Paracoccidioides brasiliensis for patients and armadillos Dasypus novemcinctus. J Clin Microbiol 41: 5735-5737.

Herr RA, Tarcha EJ, Taborda PR, Taylor JW, Ajello L, Mendoza L 2001. Phylogenetic analysis of Lacazia loboi places this previously uncharacterized pathogen within the dimorphic Onygenales. J Clin Microbiol 39: 309-314.

Hubalék Z, Nesvadbova J, Halouzka J 1998. Emmonsiosis of rodents in an agroecosystem. Med Mycol 36: 387-390.

Imai T, Sano A, Mikami Y 2000. A new PCR primer for the identification of Paracoccidioides brasiliensis based on rRNA sequences coding the internal transcribed spacers (ITS) and 5.8 regions. Med Mycol 38: 323-326.

Iwen PC, Hinrichs SH, Rupp ME 2002. Utilization of the internal transcribed spacer regions as molecular targets to detect and identify human fungal pathogens. Med Mycol 40: 87-109.

Kasuga T, Taylor JW, White TJ 1999. Phylogenetics relationships of variets and geographical groups of the human pathogenic fungus Histoplasma capsulatum darling. J Clin Microbiol 37: 653-663.

Kasuga T, White TJ, Koenig G, McEwen J, Restrepo A, Castañeda E, Lacaz CS, Heins-Vaccari EM, Freitas RS, Zancopé-Oliveira RM, Qin Z, Negroni R, Carter DA, Mikami Y, Tamura M, Taylor ML, Miller GF, Poonwan N, Taylor JW 2003. Phylogeography of the fungal pathogen Histoplasma capsulatum. Mol Ecol 12: 3383-3401.

Krivanec K, Otcenasek M, Slais J 1980. Adiaspiromycosis in large free living carnivores. Mycopathologia 71: 125-126.

Lacaz CS 1994. Historical evolution or the knowledge on paracoccidioidomycosis and its etiologic agent, Paracoccidioides brasiliensis In M Franco, CS Lacaz, A Restrepo, G Del Negro (eds.), Paracoccidioidomycosis, CRC Press, Boca Raton, 410 pp.

Liu XQ 2000. Protein-splicing intein: genetic mobility, origin and evolution. Ann Rev Genet 34: 61-76.

Macoris AS, Sugizaki MF, Peraçoli MT, Bosco SMG, Hebeler-Barbosa F, Simões LB, Theodoro RC, Trinca LA, Bagagli E 2006. Virulence attenuation and phenotypic variation of Paracoccidi- oides brasiliensis isolates obtained from armadillos and patients. Mem Inst Oswaldo Cruz 101: 331-334.

Matute DR, McEween JG, Montes BA, San-Blas G, Bagagli E, Rauscher JT, Restrepo A, Morais F, Nino-Veja G, Taylor JW 2006a. Cryptic speciation and recombination in the fungus Paracoccidioides brasiliensis as revealed by gene genealogies. Mol Biol Evol 23: 65-73.

Matute DR, Sepulveda VE, Quesada LM, Goldman GH, Taylor JW, Restrepo A, McEwen JG 2006b. Microsatellite analysis of three phylogenetic species of Paracoccidioides brasiliensis. J Clin Microbiol 44: 2153-2157.

Matute DR, Torres IP, Salgado-Salazar C, Restrepo A, McEwen JG 2007. Background selection at the chitin synthase II (chs2) locus in Paracoccidioides brasiliensis species complex. Fungal Genet Biol 44: 357-367.

McEwen JG, Ortiz BL, Garcia AM, Florez AM, Botero S, Restrepo A 1996. Molecular cloning, nucleotide sequencing and characterization of a $27-\mathrm{kDa}$ antigenic protein from Paracoccidioides brasiliensis. Fungal Genet Biol 20: 125-131.

Morais FV, Barros TF, Fukada MK, Cisalpino PS, Puccia R 2000. Polymorphism in the gene coding for the immunodominant antigen gp43 from the pathogenic fungus Paracoccidioides brasiliensis. J Clin Microbiol 38: 3960-3966.

Motoyama AB, Venancio EJ, Brandão GO, Petrofeza-Silva S, Pereira IS, Soares CM, Felipe Ms 2000. Molecular identification of Paracoccidioides brasiliensis by PCR amplification of ribosomal DNA. J Clin Microbiol 38: 3106-3109.

Naiff RD, Ferreira LCP, Barret TV, Naiff MF, Arias JR 1986. Paracoccidioidomicose enzoótica em tatus (Dasypus novemcinctus) no estado do Pará. Rev Inst Med Trop Sao Paulo 28: 19-27.

Negroni P 1966. El Paracoccidioides brasiliensis vive saprofiticamente en el suelo Argentino. Prensa Med Argent 53: 2381-2382.

Peterson SW, Sigler L 1998. Molecular genetic variation in Emmonsia crescens and Emmonsia parva, etiologic agents of adiaspiromycosis and their phylogenetic relationship to Blastomyces dermatitidis (Ajellomyces dermatitidis) and other systemic fungal pathogens. J Clin Microbiol 36: 2918-2925.

Puccia R, McEwen JG, Cisalpino PS 2008. Diversity in Paracoccidioides brasiliensis. The PbGP43 gene as a genetic marker. Mycopathologia 165: 275-287.

Restrepo A 1985. The ecology of Paracoccidioides brasiliensis: a puzzle still unsolved. J Med Vet Mycol 23: 323-334.

Restrepo A 2000. Morphological aspects of Paracoccidioides brasiliensis in lymph nodes: implications for the prolonged latency of paracoccidioidomycosis? Med Mycol 38: 317-322.

Ricci G, Silva ID, Sano A, Borra RC, Franco M 2007. Detection of Paracoccidioides brasiliensis by PCR in biopsies from patients with paracoccidioidomycosis: correlation with the histopathological pattern. Pathologica 99: 41-45.

Ricci G, Zelck U, Mota F, Lass-Flörl C, Franco MF, Bialek R 2008. Genotyping of Paracoccidioides brasiliensis directly from paraffin embedded tissue. Med Mycol 43: 31-34.

Richini-Pereira VB, Bosco SMG, Griese J, Theodoro RC, Macoris SAG, Silva RJ, Barrozo L, Tavares PMS, Zancopé-Oliveira RM 2008. Molecular detection of Paracoccidioides brasiliensis in road-killed wild animals. Med Mycol 46: 35-40.

Salina MA, Shikanai-Yasuda MA, Mendes RP, Barraviera B, Mendes-Giannini MJ 1998. Detection of circulating Paracoccidioides brasiliensis antigen in urine of paracoccidioidomycosis patients before and during treatment. J Clin Microbiol 36: 1723-1728. 
San-Blas G, Nino-Veja G, Iturriaga T 2002. Paracoccidioides brasiliensis and paracoccidioidomycosis: molecular approaches to morphogenesis, diagnosis, epidemiology, taxonomy and genetics. Med Mycol 40: 225-242.

Sano A, Tanaka R, Yokoyama K, Franco M, Bagagli E, Montenegro MR, Mikami Y, Miyaji M, Nishimura K 1999. Comparison between human and armadillo Paracoccidioides brasiliensis isolates by random amplified polymorphic DNA analysis. Mycopathologia 143: 165-169.

Sano A, Yokoyama K, Tamura M, Mikami Y, Takahashi I, Fukushima K, Miyaji M, Nishimura K 2001. Detection of gp43 and ITS15.8S-ITS2 ribosomal RNA genes of Paracoccidioides brasiliensis in paraffin-embedded tissue. Nippon Ishinkin Gakkai Zasshi 42: 23-27.

Santos VM 1999. Comportamento em cultura e diagnóstico morfológico da Emmonsia crescens em tatus. Rev Soc Bras Med Trop 32: 307 .

Shome SK, Batista AC 1963. Occurrence of Paracoccidioides brasiliensis in the soil of Recife, Brazil. Rev Fac Med Fed Ceará 3: 90-94.

Sigler L 1996. Ajellomyces crescens sp. nv., taxonomy of Emmonsia spp. and relatedness with Blastomyces dermatitidis (teleomorph Ajellomyces dermatitidis). J Med Vet Mycol 34: 303-314.

Silva-Vergara ML, Martínez R 1999. Role of the armadillo Dasypus novemcinctus in the epidemiology of paracoccidioidomycosis. Mycopathologia 144: 131-133.

Silva-Vergara ML, Martínez R, Chadu A, Madeira M, Freitas-Silva G, Leite Maffei CM 1998. Isolation of Paracoccidioides brasiliensis strain from the soil of a coffee plantation in Ibiá, state of Minas Gerais, Brazil. Med Mycol 36: 37-42.

Taborda PR, Taborda VA, McGinnis MR 1999. Lacazia loboi gen. nov., comb. nov., the etiologic agent of lobomycosis. J Clin Microbiol 37: 2031-2033.

Taylor JW, Jacobson DJ, Kroken S, Kasuga T, Geiser DM, Hibbett DS, Fisher MC 2000. Phylogenetic species recognition and species concepts in fungi. Fungal Genet Biol 31: 21-32.
Teixeira MM 2008. Tipagem molecular e evolução do gênero Paracoccidioides. Master Thesis, Faculdade de Medicina da Universidade de Brasília, Brasília, 154 pp.

Teixeira MM, Carvalho MJA, Dantas AS, Felipe MSS 2005. The hsp 70 gene presents sequence differences among isolates of Paracoccidioides brasiliensis. Rev Inst Med Trop Sao Paulo 47 (Suppl. 14): 48.

Terçarioli GR, Bagagli E, Reis GM, Theodoro RC, Bosco SMG, Macoris SAG, Richini-Pereira VB 2007. Ecological study of Paracoccidioides brasiliensis in soil: growth ability, conidia production and molecular detection. BMC Microbiol 7: 1-8.

Theodoro RC, Bagagli E, Oliveira C 2008a. Phylogenetic analysis of PRP8 intein in Paracoccidioides brasiliensis species complex. Fung Genet Biol 45: 1284-1291.

Theodoro RC, Bosco SMG, Araújo Jr JP, Candeias JMG, Macoris SAG, Trinca LA, Franco M, Bagagli E 2008b. Dimorphism, thermal tolerance, virulence and heat shock protein 70 transcription in different isolates of Paracoccidioides brasiliensis. Mycopathologia 165: 355-365.

Theodoro RC, Candeias JMG, Araújo Jr JP, Bosco SMG, Macoris SAG, Padula Jr LO, Franco M, Bagagli E 2005. Molecular detection of Paracoccidioides brasiliensis in soil. Med Mycol 43: 725-729.

Untereiner WA, Scott JA, Naveau FA, Sigler L, Bachewish J, Angus A 2004. The Ajellomycetaceae, a new family of vertebrate-associate Onygenales. Mycol 96: 812-821.

Wanke B, Londero AT 1994. Epidemiology and paracoccidioidomycosis infection. In M Franco, CS Lacaz, G Del Negro (eds.), Paracoccidioidomycosis, CRC Press, Boca Raton, p. 109-120.

White TJ, Brunis T, Lee S, Taylor J 1990. Amplification and direct sequencing of fungal ribossomal RNA genes for phylogenetics. In MA Innis, DH Gelfand, JJ Sninsky, TJ White (eds.), PCR protocols - a guide to methods and applications, Academic Press Inc, San Diego, p. 315-322.

Zlatonov Z, Genov T 1975. Isolation of Emmonsia crescens et Jellison 1960 from small mammals in Bulgaria. Mycopathol 56: 1-3. 